\title{
Vertical distribution of dry mass in cereals straw and its loss during harvesting
}

\author{
T. Zajacc ${ }^{1}$, A. Oleksy ${ }^{1}$, A. Stokłosa ${ }^{2}$, A. Klimek-Kopyra ${ }^{1}$, and J. Macuda ${ }^{3}$ \\ ${ }^{1}$ Institute of Crop Production, ${ }^{2}$ Department of Agrotechnology and Agricultural Ecology, University of Agriculture, \\ Mickiewicza 21, 31-120 Cracow, Poland \\ ${ }^{3}$ Department of Oil Engineering, AGH University of Science and Technology, Mickiewicza 30, 30-059 Cracow, Poland
}

Received June 13, 2011; accepted November 02, 2011

\begin{abstract}
A b s t r a c t. The study aimed at evaluating the distribution of mass in the straw of cereal species and also at assessing the straw yield and its losses resulting from the amount of the stubble left in the field. It was found empirically that the wheat culms are composed of five internodes, and in barley, triticale and oats of six. The highest straw mass per $1 \mathrm{~cm}$ was found in the second internode in both forms of wheat and winter triticale, whereas barley and oats gathered the highest weight in the first internode. In the southern part of Silesia species and forms of cereals differed in the straw yield, which can be arranged as follows, from the highest: winter wheat $>$ spring wheat, winter triticale, winter barley, and oats $>$ spring barley. Due to the specific distribution of dry matter in each of internodes of both wheat forms - winter and spring, they loose less stubble mass ( 22 and 24\%, respectively), comparing to other cereals, especially spring barley, which loose $31 \%$ yield of straw in the stubble of $15 \mathrm{~cm}$ height. loss

K e y w o r d s: cereal species, culm, internodes, straw yield
\end{abstract}

\section{INTRODUCTION}

The grain yield of cereal species and cultivars has been the main area of interest of agricultural science and practice since the second half of 20. century (Noworolnik, 2007; Podolska, 1999; Sticksel et al., 2000; Tripathi et al., 2003). Plant breeding programs were the main creator of increasing cereals productivity in this period, called 'a green revolution', when cultivars of shorter straw and higher yielding, thanks to increased number of ears or panicles per area, were bred (Fufa et al., 2005; Podlaski, 2007, Sener et al., 2009). Anatomical and morphological properties of cereals' culm are well identified both, on botanical and agricultural level (Budzyński and Szempliński, 2003; Singh et al., 2011). The length and flexibility of cereal culms decides on canopy resistance to lodging. Introduction of growth retardants in the cereals growing, allowed efficient decrease of culm length and, as a consequence, improved canopy resistance to lodging (Berry et al., 2000; Olumekun, 1996; Tripathi et al., 2003). Valuation of morphological changes, namely cell thickness, diameter and length of internodes, in the response to retardants usage, has an important scientific aspect (Masanori et al., 2010; Sanvicente et al., 1999; Tripathi et al., 2003).

Nowadays, cereals straw is recognized as a significant source of renewable energy but still its energetic value is strongly dependent on the moisture content (Tavakoli et al., 2009). Each year a nationwide straw yield accounts for $c a$. 24-29 mln t, of which 4-5 mln $\mathrm{t}$ may be intended for energetic purposes (Kuś et al., 2006). In the recent years straw has also become a significant source of mass applied to the soil (Pabin et al., 2003), with a significant reduction of its role as the animals feed (Gauder et al., 2011; Summers et al., 2003). Nonetheless, research on feeding value of cereals straw are still carried out, including genetic source of its changeability, for improving the quality of winter wheat and barley roughage (Jensen et al., 2011; Mgheni et al., 2001).

Interest in the straw, as a side-line crop, has been insignificant in the most of research focused mainly on increasing the grain yield per plant or per area (Przulj and Momcilovic, 2001; Sticksel et al., 2000). Also, the prognostic models used to assess the increase of aboveground mass yield of cereals, mostly wheat, aim at the grain yield, whereas the straw yield is being discounted (Lawless et al., 2005; Zalud et al., 2003). Harvest index proposed by Donald (1962) expressing the share of grain in the single plant or in the canopy is widely used in the scientific research, mainly plant breeding, as it shows accurately the quantity of grain involved in the yield of aboveground mass and is an effective factor in the selection within the single plant, the strains and 
cultivars. Harasim (1994) was trying to develop a methodology to assess the cereals straw mass for agricultural practice, which turned out to be ineffective, because it did not include the current straw moisture and also missed the importance of straw losses during harvesting, resulting from the height of the stubble. Moreover, its common application reduces the need to weigh the yield of grain and straw from the field at harvest time, which is also difficult to implement, as the majority of farms are without balances. For those reasons Kuś et al. (2006) admit, that assessing the straw yield is difficult, both on the regional or the national scale.

One can expect, that the mass of straw, left in the field as a stubble, depends both, on the length of the culms and the cutting height. For that reason it seems obvious that the straw losses will be different for different species and forms of cereals - winter or spring. Answering to these questions is difficult because of the lack of discernment relating to the vertical distribution of the straw yield in the culms and canopy of modernly grown species and forms of cereals.

The purpose of our study was to clearly define:

- the distribution of mass in the straw of cereal species,

- the straw yield and its losses resulting from the amount of the stubble left in the field, determined by the properties of the straw's lower internodes.

\section{MATERIAL AND METHODS}

In the year 2010 in the south part of Silesia in three districts: cieszyński, pszczyński and bielski the analysis of the straw yield of the most commonly grown species of winter and spring cereals was undertaken. The measurements included species as follow: spring and winter wheat (Triticum aestivum L.), spring and winter barley (Hordeum sativum Pers.), winter triticale (x Triticosecale Wittm. ex. A. Camus) and oats (Avena sativa L.). The crop fields, where the complex agricultural practices on the level $\mathrm{a}_{1}$ are carried out (no use of growth retardants), were chosen to the analyses. Each cereal species and form was picked up from 30 different fields. Before harvest on each of those fields from 5 different places, located diagonally across the field, of $1 \mathrm{~m}^{2}$ area each, the number of ears was counted and also 10 culms were taken for further analyses. After culms reduction the samples of minimum 100 pieces were chosen to the final measurements and placed in the airy barn for slow drying.

The biometric measurements included: the number, length, diameter and mass of each of internodes. Internodes diameter was measured in the middle of their length, using electronic caliper Yato- $7201{ }^{\circledR}$. The length of ears or panicles as well as the mass of seeds per each inflorescence was also counted. After measurements plant culms and inflorescence were put separately in the plastic bags, which were placed in the metal dishes and put to the dryer for $72 \mathrm{~h}$ in $75^{\circ} \mathrm{C}$. The straw mass of each of internodes as well as the straw yield was presented at $15 \%$ of water content.

The following parameters were calculated: density of mass per $1 \mathrm{~cm}^{2}$ (Sanvicente et al., 1999) for each internode, harvest index (Donald, 1962), the final straw yield ( $\mathrm{t} \mathrm{ha}^{-1}$, calculated on the basis of single culm mass and their number per $1 \mathrm{~m}^{2}$ ). The loss of straw yield was calculated based on 3 different heights of cutting: 5, 10 and $15 \mathrm{~cm}$.

The results were analyzed using one-way ANOVA, and also the regression equations were calculated, to assess the level of interdependence between tested traits.

\section{RESULTS}

Among the cereals tested, winter wheat developed the longest shoots. Comparing to winter barley and winter triticale they were longer by about $6 \%$ and $13 \%$, respectively (Table 1). Among spring cereals shoots of both, spring wheat and oats, were of similar height and by about $30 \%$ longer than spring barley shoots, which were the shortest among all cereal species tested. A moderate correlation between mass and length of oats culm $\left(\mathrm{R}^{2}=0.53\right)$, winter wheat $\left(\mathrm{R}^{2}=0.32\right)$ and winter triticale $\left(\mathrm{R}^{2}=0.30\right)$ was noted (Fig. 1$)$. The other species showed poor correlation of both traits, what suggests that culm elongation is not linearly correlated with culm mass.

T a b l e 1. Comparison of the density of straw $\left(\mathrm{pcs}\right.$ per $\left.1 \mathrm{~m}^{2}\right)$, length $(\mathrm{cm})$ and mass $(\mathrm{g})$ of culm and inflorescence - components of cereal shoot, including harvest index

\begin{tabular}{|c|c|c|c|c|c|c|c|c|}
\hline \multirow{2}{*}{ Species } & \multirow{2}{*}{$\begin{array}{l}\text { Density } \\
\text { of straw }\end{array}$} & \multicolumn{2}{|c|}{ Culm } & \multicolumn{2}{|c|}{ Ear (panicle) } & \multicolumn{2}{|c|}{ Shoot } & \multirow{2}{*}{$\begin{array}{c}\text { Harvest } \\
\text { index }\end{array}$} \\
\hline & & Length & Mass & Length & Mass & Length & Mass & \\
\hline Winter wheat & $472 \pm 19.5$ & $86.9 \pm 5.2$ & $1.52 \pm 0.25$ & $8.1 \pm 0.7$ & $1.81 \pm 0.35$ & $95.0 \pm 5.2$ & $3.33 \pm 0.57$ & $0.45 \pm 0.02$ \\
\hline Winter barley & $420 \pm 20.2$ & $83.1 \pm 6.2$ & $1.18 \pm 0.25$ & $6.0 \pm 0.9$ & $1.36 \pm 0.34$ & $89.1 \pm 6.3$ & $2.55 \pm 0.56$ & $0.44 \pm 0.03$ \\
\hline Triticale & $414 \pm 25.0$ & $74.8 \pm 6.0$ & $1.23 \pm 0.37$ & $7.8 \pm 1.0$ & $1.76 \pm 0.65$ & $82.5 \pm 6.5$ & $2.99 \pm 0.96$ & $0.48 \pm 0.05$ \\
\hline Spring wheat & $459 \pm 22.4$ & $78.4 \pm 5.5$ & $1.17 \pm 0.26$ & $8.0 \pm 0.8$ & $1.52 \pm 0.44$ & $86.4 \pm 5.6$ & $2.70 \pm 0.66$ & $0.46 \pm 0.03$ \\
\hline Spring barley & $451 \pm 24.4$ & $54.7 \pm 5.0$ & $0.61 \pm 0.13$ & $6.0 \pm 0.6$ & $0.87 \pm 0.17$ & $60.7 \pm 5.2$ & $1.49 \pm 0.26$ & $0.48 \pm 0.04$ \\
\hline Oats & $401 \pm 28.1$ & $72.2 \pm 7.5$ & $1.17 \pm 0.37$ & $14.3 \pm 1.9$ & $1.54 \pm 0.60$ & $86.6 \pm 8.1$ & $2.71 \pm 0.85$ & $0.46 \pm 0.07$ \\
\hline $\mathrm{LSD}_{\mathrm{p}=0.05}$ & n.s. & 2.44 & 0.116 & 0.44 & 0.186 & 2.56 & 0.279 & 0.018 \\
\hline
\end{tabular}



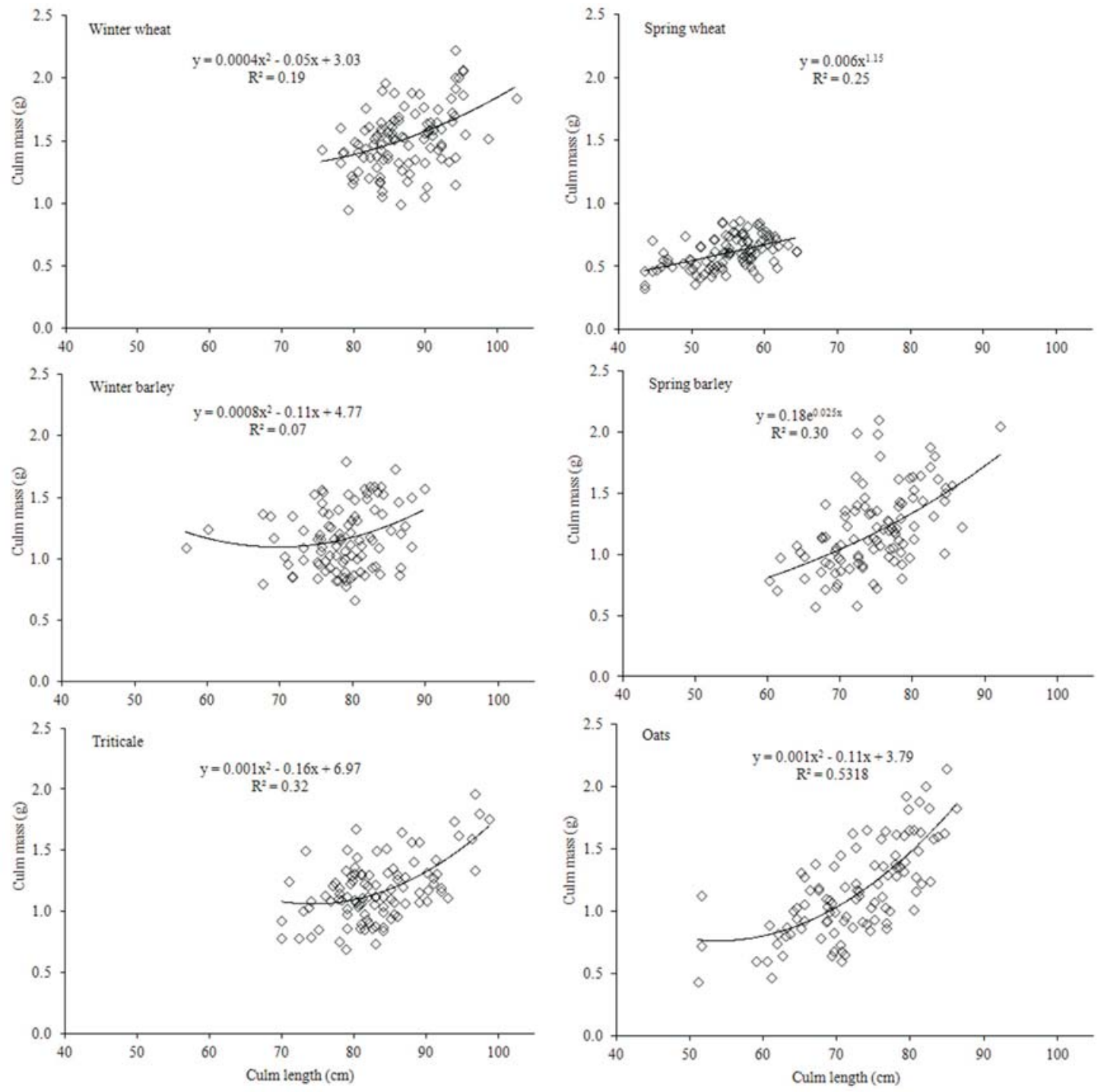

Fig. 1. Correlation between culm mass and length of tested cereals $(n \geq 100)$.

Ears of similar mass were developed by both forms of wheat and winter triticale (Table 1). Both barley forms had shorter ears, which is species-specific trait. Oats is a difficult cereal for this kind of inflorescence comparison between species, as it develops panicles. Plants of winter wheat in a full grain maturity phase had the highest shoot mass, whereas spring barley - the lowest. At the same time the harvest index was the highest for spring barley and winter triticale. Correlation values calculated for mass of culm and harvest index (Fig. 2), confirm poor link between those two traits, except spring barley, where correlation was moderate $\left(\mathrm{R}^{2}=0.33\right)$.

Culms of both forms of wheat were composed of 5 internodes, whereas the other cereal species had 6 internodes. The shortest, as expected, were the basal internodes, especial- ly the first one (Table 2). Oats first internode was significantly shorter, comparing to the other species. The length of subsequent internodes was increasing. The share of shank in the culm length was generally the biggest, especially for oats and spring wheat, where it was by about $44 \%$ of all culm length. The third internodes were the thickest for most of the species, except winter barley, which second internode was the thickest one. For oats and spring wheat also a linear increase in the mass of internodes was noted. For the other cereal species, the highest mass was noted for penultimate internode.

Distribution of mass per unit area was different, in three species, namely winter and spring barley and oats, where it was constantly decreasing with height. For the other cereals the highest mass per unit area was noted in the second internode, and then it was decreasing with height (Table 2). Based on the characteristics of stem internodes, it was 

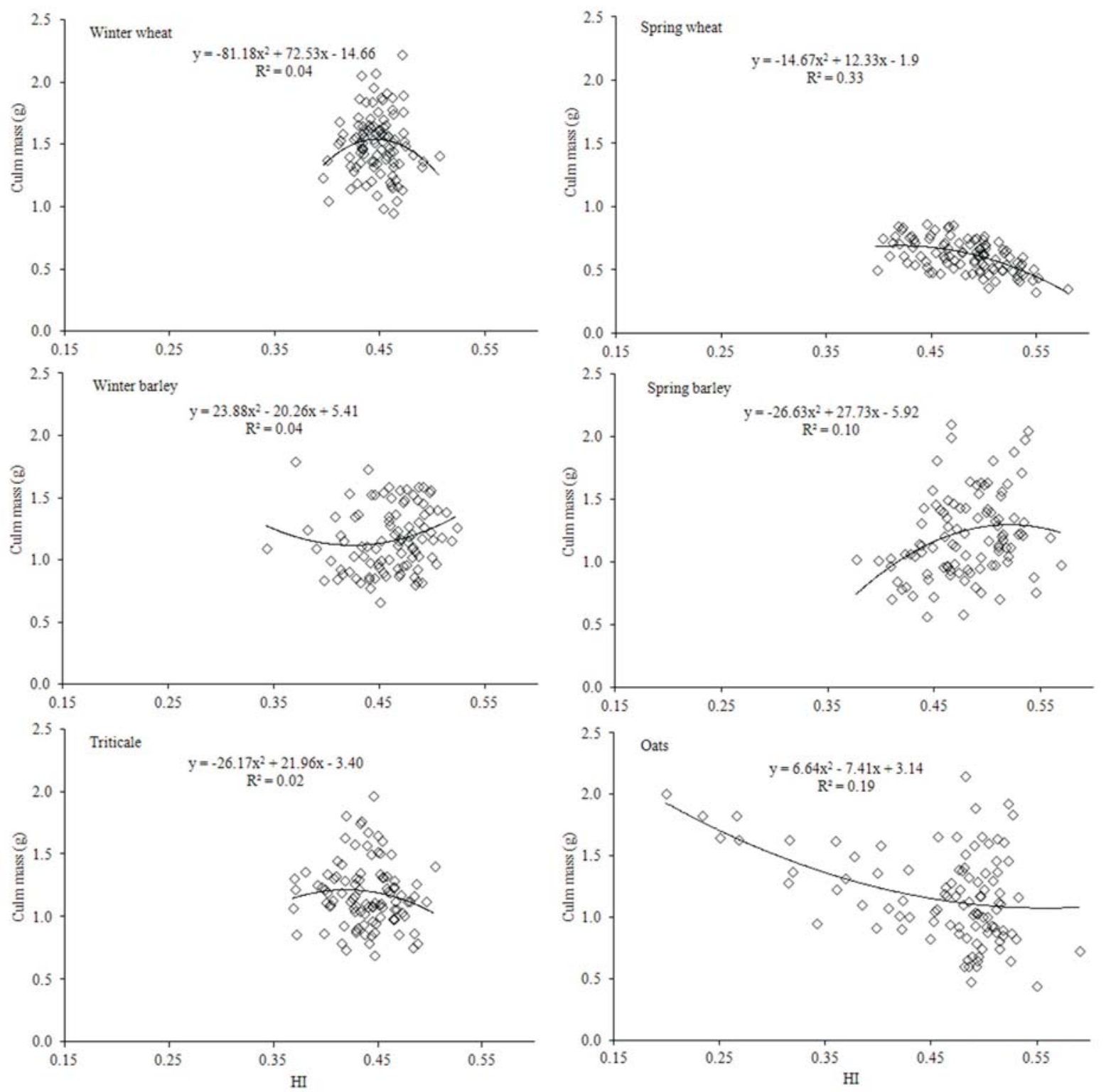

Fig. 2. Correlation between culm mass and harvest index of tested cereals $(n \geq 100)$.

estimated, that only few of them (II - IV) contributed to the total mass of a single straw. In cereal species namely, winter barley, spring barley and triticale, this contribution amounted to 72,56 , and $65 \%$, respectively. In both forms of wheat and also oats the major part in creating mass of a single straw had the two highest internodes, the penultimate and the shank ones.

At harvest, at three heights of cutting, the single straw losses had a linear trend (Table 3 ). Because of a short straw the biggest losses were found for a spring barley. On the other hand, for both forms of wheat the lowest losses were noted, due to the specific allocation of mass in their internodes; as showed earlier, the highest contribution in wheat straw mass had the 4th and the 5th internodes (Table 2).

The highest straw yield was achieved for winter wheat, and the lowest for spring barley (Table 4). Yield of the other cereal species was similar. The higher yields for both wheat forms may be explained by their best stand in the crop rotation, as they have high cultivation requirements. The assessed straw yield losses, when cut at $15 \mathrm{~cm}$ height, were in a range between 0.86 (for spring barley) to $1.58 \mathrm{t} \mathrm{ha}^{-1}$ (for winter wheat). Even though the absolute values of straw loss were 
T a b l e 2. Comparison of the length, mass, and mass per $1 \mathrm{~cm}$ diameter of cereal internodes

\begin{tabular}{|c|c|c|c|c|c|c|}
\hline \multirow{2}{*}{ Species } & \multicolumn{6}{|c|}{ Internode number } \\
\hline & I & II & III & IV & V & VI \\
\hline & \multicolumn{6}{|c|}{ Length (cm) } \\
\hline Winter wheat & $3.1 \pm 1.4$ & $9.6 \pm 1.8$ & $16.6 \pm 1.4$ & $25.1 \pm 1.1$ & $33.1 \pm 2.7$ & - \\
\hline Winter barley & $3.1 \pm 1.9$ & $11.0 \pm 2.4$ & $16.1 \pm 2.2$ & $20.4 \pm 2.9$ & $25.1 \pm 4.1$ & $25.2 \pm 3.6$ \\
\hline Triticale & $3.7 \pm 2.1$ & $8.0 \pm 1.9$ & $13.6 \pm 1.7$ & $19.2 \pm 3.2$ & $23.6 \pm 3.9$ & $22.5 \pm 2.9$ \\
\hline Spring wheat & $3.2 \pm 1.5$ & $7.9 \pm 1.6$ & $14.0 \pm 1.0$ & $20.6 \pm 1.5$ & $35.0 \pm 2.1$ & - \\
\hline Spring barley & $2.5 \pm 1.2$ & $8.0 \pm 1.0$ & $10.2 \pm 1.6$ & $10.5 \pm 1.5$ & $12.8 \pm 1.2$ & $11.7 \pm 2.0$ \\
\hline Oats & $1.4 \pm 0.6$ & $5.5 \pm 1.5$ & $9.1 \pm 1.2$ & $10.2 \pm 1.3$ & $17.5 \pm 1.3$ & $32.0 \pm 3.4$ \\
\hline \multirow[t]{2}{*}{$\mathrm{LSD}_{\mathrm{p}=0.05}$} & 0.85 & 1.05 & 0.87 & 1.15 & 1.55 & 2.04 \\
\hline & \multicolumn{6}{|c|}{ Mass (g) } \\
\hline Winter wheat & $0.06 \pm 0.03$ & $0.22 \pm 0.05$ & $0.35 \pm 0.07$ & $0.47 \pm 0.09$ & $0.43 \pm 0.09$ & - \\
\hline Winter barley & $0.08 \pm 0.05$ & $0.25 \pm 0.06$ & $0.31 \pm 0.07$ & $0.30 \pm 0.06$ & $0.25 \pm 0.06$ & $0.23 \pm 0.04$ \\
\hline Triticale & $0.08 \pm 0.04$ & $0.20 \pm 0.05$ & $0.27 \pm 0.07$ & $0.35 \pm 0.09$ & $0.31 \pm 0.10$ & $0.26 \pm 0.09$ \\
\hline Spring wheat & $0.05 \pm 0.03$ & $0.16 \pm 0.11$ & $0.24 \pm 0.05$ & $0.36 \pm 0.07$ & $0.44 \pm 0.11$ & - \\
\hline Spring barley & $0.04 \pm 0.02$ & $0.10 \pm 0.03$ & $0.12 \pm 0.03$ & $0.12 \pm 0.03$ & $0.13 \pm 0.03$ & $0.09 \pm 0.02$ \\
\hline Oats & $0.04 \pm 0.02$ & $0.12 \pm 0.05$ & $0.19 \pm 0.05$ & $0.20 \pm 0.06$ & $0.32 \pm 0.10$ & $0.42 \pm 0.13$ \\
\hline \multirow[t]{2}{*}{$\mathrm{LSD}_{\mathrm{p}=0.05}$} & 0.019 & 0.034 & 0.032 & 0.039 & 0.048 & 0.063 \\
\hline & \multicolumn{6}{|c|}{ Dry mass per unit length $\left(\mathrm{mg} \mathrm{cm}^{-1}\right)$} \\
\hline Winter wheat & $21.1 \pm 6.0$ & $23.1 \pm 4.1$ & $21.2 \pm 4.9$ & $18.5 \pm 3.2$ & $13.0 \pm 2.1$ & - \\
\hline Winter barley & $26.3 \pm 8.6$ & $22.7 \pm 4.9$ & $19.2 \pm 4.0$ & $15.0 \pm 3.4$ & $10.5 \pm 3.5$ & $9.3 \pm 1.7$ \\
\hline Triticale & $20.6 \pm 6.8$ & $22.7 \pm 6.5$ & $20.2 \pm 5.0$ & $18.3 \pm 4.9$ & $13.6 \pm 4.8$ & $11.6 \pm 3.0$ \\
\hline Spring wheat & $16.0 \pm 5.6$ & $20.8 \pm 7.6$ & $17.5 \pm 4.0$ & $17.4 \pm 3.5$ & $12.5 \pm 2.6$ & - \\
\hline Spring barley & $15.2 \pm 5.8$ & $12.7 \pm 3.0$ & $12.1 \pm 2.4$ & $11.4 \pm 2.3$ & $9.9 \pm 1.7$ & $8.2 \pm 2.4$ \\
\hline Oats & $26.1 \pm 9.6$ & $21.2 \pm 6.1$ & $20.8 \pm 5.7$ & $19.1 \pm 5.2$ & $17.9 \pm 4.5$ & $13.0 \pm 3.1$ \\
\hline \multirow[t]{2}{*}{$\mathrm{LSD}_{\mathrm{p}=0.05}$} & 4.01 & 4.76 & 2.41 & 2.15 & 1.90 & 1.78 \\
\hline & \multicolumn{6}{|c|}{ Diameter (mm) } \\
\hline Winter wheat & $3.24 \pm 0.30$ & $3.82 \pm 0.35$ & $4.32 \pm 0.39$ & $4.07 \pm 0.42$ & $2.71 \pm 0.27$ & - \\
\hline Winter barley & $3.49 \pm 0.39$ & $4.98 \pm 0.29$ & $4.73 \pm 0.74$ & $4.26 \pm 0.50$ & $3.18 \pm 0.78$ & $2.55 \pm 0.31$ \\
\hline Triticale & $3.46 \pm 0.38$ & $4.15 \pm 0.52$ & $4.45 \pm 0.59$ & $4.35 \pm 0.62$ & $3.34 \pm 0.93$ & $2.41 \pm 0.34$ \\
\hline Spring wheat & $2.71 \pm 0.36$ & $3.39 \pm 0.28$ & $3.45 \pm 0.29$ & $3.58 \pm 0.31$ & $2.81 \pm 0.32$ & - \\
\hline Spring barley & $2.67 \pm 0.34$ & $3.19 \pm 0.37$ & $3.18 \pm 0.43$ & $3.09 \pm 0.39$ & $2.82 \pm 0.50$ & $1.81 \pm 0.23$ \\
\hline Oats & $3.11 \pm 0.65$ & $4.17 \pm 0.56$ & $4.54 \pm 0.54$ & $4.32 \pm 0.68$ & $3.96 \pm 0.57$ & $2.89 \pm 0.49$ \\
\hline $\mathrm{LSD}_{\mathrm{p}=0.05}$ & 0.353 & 0.787 & 0.426 & 0.423 & 0.502 & 0.463 \\
\hline
\end{tabular}

the highest for winter wheat, taking into account the high straw yield of this species, the percentage value of loss was low, and accounted as $22 \%$. In case of spring barley, the percentage loss of straw yield was the highest among all species tested, $31 \%$ when cut at $15 \mathrm{~cm}$.

\section{DISCUSSION}

The systematic introduction to the growing the cereal cultivars of short-straw has led to an increase in productivity, usually related to the grain yield. The stem and culm length 
T a b l e 3. Projected harvest losses of single cereal culm mass (g), depending on the height of stubble

\begin{tabular}{lccc}
\hline & \multicolumn{3}{c}{ Cutting height $(\mathrm{cm})$} \\
\cline { 2 - 4 } Species & 5 & 10 & 15 \\
\hline Winter wheat & $0.11 \pm 0.03(7)^{*}$ & $0.22 \pm 0.04(15)$ & $0.33 \pm 0.06(22)$ \\
Winter barley & $0.12 \pm 0.03(10)$ & $0.24 \pm 0.05(20)$ & $0.34 \pm 0.07(29)$ \\
Triticale & $0.11 \pm 0.03(9)$ & $0.22 \pm 0.05(18)$ & $0.32 \pm 0.08(26)$ \\
Spring wheat & $0.10 \pm 0.07(8)$ & $0.19 \pm 0.11(16)$ & $0.28 \pm 0.12(24)$ \\
Spring barley & $0.07 \pm 0.02(11)$ & $0.13 \pm 0.03(21)$ & $0.19 \pm 0.04(31)$ \\
Oats & $0.11 \pm 0.03(10)$ & $0.22 \pm 0.06(19)$ & $0.32 \pm 0.08(27)$ \\
\hline
\end{tabular}

*Relative culm mass losses (\%) in parentheses.

T a b I e 4. Estimation thetotal straw yield and its losses related to the three cutting heights

\begin{tabular}{lcccc}
\hline \multirow{2}{*}{ Species } & $\begin{array}{c}\text { Total straw yield } \\
\left(\mathrm{t} \mathrm{ha}^{-1}\right)\end{array}$ & 5 & \multicolumn{3}{c}{ Cutting height $(\mathrm{cm})$} \\
\cline { 3 - 5 } Winter wheat & 7.17 & 0.51 & 10 & 15 \\
Winter barley & 4.97 & 0.52 & 0.99 & 1.58 \\
Triticale & 5.09 & 0.44 & 0.90 & 1.44 \\
Spring wheat & 5.39 & 0.43 & 0.88 & 1.33 \\
Spring barley & 2.77 & 0.31 & 0.59 & 0.86 \\
Oats & 4.69 & 0.45 & 0.88 & 1.29 \\
LSD $_{\mathrm{p}=0.05}$ & 0.496 & 0.096 & 0.158 & 0.192
\end{tabular}

found in the field studies shows that cultivars of a relatively short straw are dominant in the growing, and this founding is confirmed by the value of harvest index, which is relatively high. The straw yield of tested cereals, assessed in the field conditions of south Silesia, is as follows $\left(\mathrm{t} \mathrm{ha}^{-1}\right)$ : winter wheat $-7.17>$ spring wheat -5.39 , winter triticale -5.09 , winter barley -4.97 , oats $-4.69>$ spring barley -2.77 . In the field experiments the straw yield is usually formed over a wide range (Przulj and Momcilovic, 2001; Summers et al., 2003). In the domestic field experiments with cereals, the straw yield, as an indicator of canopy productivity, is usually omitted. Recently, as the interest in energetic use of straw is increasing, research on potential use of straw for this purposes are developing (Gauder et al., 2011), still method proposed by Authors is based on a complicated mathematical formulas. This may cause dilemmas during assessing a straw yield of the particular cereal species. Those days an urgent need for developing the objective measures of straw yield on the one hand, and reliable quantitative and prognostic guidelines as to the disposal of its collections on the other, is arising. The yield of straw depends on many factors $i e$ mineral fertilization (Jarosch et al., 2008), growth regulators (Rajala and Peltonen-Sainio, 2001).
The culms of compared forms and species of cereals were composed of 5 or 6 internodes for wheat and other species, respectively. The average length $(\mathrm{cm})$ of culms of each species was as follows: winter wheat -86.9 , winter barley -83.1 , spring wheat -78.4 , winter triticale -74.8 , oats -72.2 and spring barley -54.7 . Fufa et al. (2005) points out the decreasing trend in the length of wheat straw in the last decades. Austin et al. (1989) assessed, using a multiple regression analysis, that in the last 150 years of wheat growing, its grain yield increased by about $59 \%$, whereas the straw yield decreased by about $21 \%$, as a result of culm shortening (by 46\%). Those data, in the most complete way, present the achievements of wheat breeding programs.

Although clear and understandable is fact of a positive correlation between culm length and its mass, our result have showed just a moderate correlation for oats $\left(\mathrm{R}^{2}=0.53\right)$, winter wheat $\left(R^{2}=0.32\right)$ and winter triticale $\left(R^{2}=0.30\right)$. The other species showed poor correlation of both traits. The presence of culms of different hierarchies in the cereal canopy may serve an explanation of those dependencies. In the canopy of winter wheat there are three fractions of culm height: high, medium and low (Podolska, 1999). In the optimal sowing date of wheat the share of straws in creating the 
grain yield was of $36 \%$ for high, $45 \%$ for medium and $27 \%$ for low. When the sawing date was delayed, the share of straw fractions was as follows: $63 \%$ for high, $30 \%$ for medium and $7 \%$ for low straws.

\section{CONCLUSIONS}

1. Culms of wheat were composed of 5 internodes, whereas in other cereals of 6 internodes. In both forms of wheat and winter triticale, the highest mass of $1 \mathrm{~cm}$ of straw was found in the second internode, in both forms of barley and oats, in the first internode. Mass of $1 \mathrm{~cm}$ of straw decreased steadily towards the top of the culm.

2. Cereal species differed in the straw yield, and are ranked as follows: winter wheat $>$ spring wheat, winter triticale, winter barley, oats $>$ spring triticale.

3. The lowest loss of straw yield, resulting from the straw cutting at $15 \mathrm{~cm}$, was noted for both forms of wheat (22 and 24\% for winter and spring wheat, respectively), and the highest for spring barley (31\%).

\section{REFERENCES}

Austin R.B., Ford M.A., and Morgan C.L., 1989. Genetic improvement in the field of winter wheat: a further evaluation. J. Agric. Sci. (Cam.), 112, 295-301.

Berry P.M., Griffin J.M., Sylvester-Bradley R., Scott P.K., Spink J.H., Boker C.J., and Clare R.W., 2000. Controlling plant from through husbandry to minimize lodging in wheat. Field Crop Res., 67, 59-81.

Budzyński W. and Szempliński W., 2003. Biology of development (in Polish). In: Szczegółowa Uprawa Roślin (Eds Z. Jasińska, A. Kotecki). AWA Press, Wrocław, Poland.

Donald C.M., 1962. In search of yield. J. Aust. Inst. Agric. Sci., 28, 171-178.

Fufa H., Baenziger P.S., Beecher B.S., Graybosch R.A., Eskridge K.M., and Nelson L.A., 2005. Genetic improvement trends in agronomic performances and end-use quality characteristics among hard red winter wheat cultivars in Nebraska. Euph., 144, 187-198.

Gauder M., Graeff-Honninger S., and Claupen W., 2011. Identifying the regional straw potential for energetic use on the basis of statistical information. Biom. Bioen., 35, 1646-1654.

Harasim A., 1994. Relationship between the yield of grain and straw in cereals (in Polish). Pamiętnik Puławski, 104, 51-59.

Jarosch A.M., Neumann E., Oltmanns M., and Raupp J., 2008. Yield and arbuscular mycorrhiza fungal root colonization of organically or minerally fertilized wheat grown on a sandy soil. 17th Int. Symp. CIEC, November 24-27, Cairo, Egypt.

Jensen J.W., Magid J., Hansen-Moller J., Andersen S.B., and Bruun S., 2011. Genetic variation in degrability of wheat straw and potential for improvement through plant breeding. Biom. Bioen., 35, 1114-1120.

Kuś J., Madej A., and Kopiński J., 2006. Balans of straw in regional terms (in Polish). In: Regional differentiation of agricultural production in Poland (Ed. A. Harasim). Raporty IUNG-PIB, Puławy, Poland.

Lawless C., Semenov M.A., and Jamieson P.D., 2005. A wheat canopy model linking leaf area and phenology. Eur. J. Agron., 22, 19-32.
Masanori T., Shiotsu F., Bian J., Morokuma M., and Kusutani A., 2010. Effects of reduction in plant height induced by chlor mequat on radiation interception and radiation-use efficiency in wheat in Southwest Japan. Plant Prod. Sci., 13, 67-73.

Mgheni D.M., Ndemanisho E.E., Hvelplund T., and Weisbjerg M.R., 2001. Evaluation of the feeding value of two tropical cereal straws, maize stover, rice straw and their botanical fractions by nylon and mobile bag technique. African J. Sci. Technol., 2, 65-71.

Noworolnik K., 2007. Principles of optimum production technology for the cereals (in Polish). Post. Nauk Roln., 326(1), 31-48.

Olumekun V.O., 1996. An analysis of the response of winter wheat (Triticum aestivum) to Cycocel (Chlormequat) application. J. Agron. Crop Sci., 176, 145-150.

Pabin J., Lipiec J., Wolek S., and Biskupski A., 2003. Effect of different tillage systems and straw management on some physical properties of soil and on the yield of winter rye in monoculture. Int. Agrophysics, 17, 175-181.

Podlaski S., 2007. The impact of breeding progress on plant production (in Polish). Post. Nauk Roln., 326, 3-22.

Podolska G., 1999. The structure and output of winter wheat as affected by selected agronomic factors and plant model (in Polish). Pamiętnik Puławski, 116, 7-133.

Przulj N. and Momcilovic V., 2001. Genetic variation for dry matter and nitrogen accumulation and translocation in tworowed spring barley I. Dry matter yield translocation. Eur. J. Agron., 15, 241-254.

Rajala A. and Peltonen-Sainio P., 2001. Plant growth regulator effects on spring cereal root and shoot growth. Agron. J., 93, 936-943.

Sanvicente P., Lazarevitch S., Blouet A., and Guckert A., 1999. Morphological and anatomical modification in winter barley culm after late plant growth regulator treatment. Eur. J. Agron., 11, 45-51.

Sener O., Arslan M., Soysal Y., and Erayman M., 2009. Estimates of relative yield potential and genetic improvement of wheat cultivars in the Mediterranean region. J. Agric. Sci., $147,323-332$

Singh S., Dutt D., and Tyagi C.H., 2011. Complete characterization of wheat straw (Triticum aestivum PBW-343 L. Emend. Fiori and Paol.) - a renewable source of fibres for pulp and paper making. BioResour., 6, 154-177.

Sticksel E., Maidl F.X., Retzer F., Dennert J., and Fischbeck G., 2000. Efficiency of grain production of winter wheat as affected by $\mathrm{N}$ fertilization under particular consideration of single culm sink size. Eur. J. Agron., 13, 287-294.

Summers M.D., Jenkins B.M., Hyde P.R., Williams J.F., Mutters R.G., Scardacci S.C., and Hair M.W., 2003. Mass production and allocation in rice with implications for straw harvesting and utilization. Biom. Bioen., 24, 163-173.

Tavakoli H., Mohtasebi S.S., and Jafari A., 2009. Physical and mechanical properties of wheat straw as influenced by moisture content. Int. Agrophys., 23, 175-181.

Tripathi S.C., Sayre K.D., Kaul J.N., and Narang R.S., 2003. Growth and morphology of spring wheat (Triticum aestivum L.) culms and their association with lodging: effect of genotypes, N levels and etephon. Field Crop Res., 84, 271-290.

Zalud Z., McMaster G.S., and Wilhelm W.W., 2003. Evaluating SHOOTGRO 4.0 as a potential winter wheat management in the Czech Republic. Eur. J. Agron., 19, 495-507. 